\title{
Analysis on the Operation Mode of Government Venture Capital Guidance Fund
}

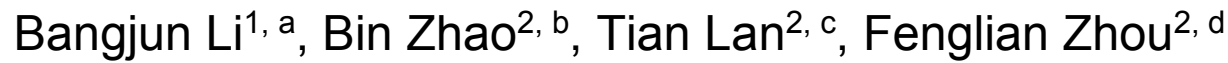

${ }^{1}$ Department of Information management, Chengdu Neusoft University, Chengdu 611844, China;

2Department of Business management, Chengdu Neusoft University, Chengdu 611844, China.

a290332181@qq.com, b314093915@qq.com, c936347894@qq.com, d741924611@qq.com

\begin{abstract}
It is a common way for government around the world to support venture capital through establishing venture capital funds. The mode of venture capital of different countries to guide the fund can be classified according to different operation mode, and summarize the experience, in order to play a certain role in our country government's venture capital funds.
\end{abstract}

Keywords: Venture Capital, Guidance Fund, Operation Mode.

\section{Mode Division of Guidance Fund in Various Countries}

According to the different operation modes of the government's venture capital guiding funds in developed countries and regions, the typical guiding fund operation models abroad are divided into three following categories.

\subsection{Fund Participation Model}

The governments of Israel and Australia began to invest in government funds in 1990s, in order to guide the development of related industries through the mode of fund participation. The government intervened less in its participating enterprises or funds and did not compete with the people. Most of the fund profits were beneficial to the people, which promoted the development of venture capital industry.

Israel is a more developed risk investment in the world. Its venture capital sprouted in the $60 \mathrm{~s}$ of last century, like other developed countries. And came to the end of the 1990s, with the continuous listing of a large number of Israeli high-tech companies in NASDAQ, Israel's venture investors gained substantial returns. In 1991, the Israeli government established a government investment guidance fund (YOZMA) by investing 100 million US dollars with Israeli and foreign professional investment institutions. The selected investment institutions are internationally known investment institutions. In the venture capital guidance fund, the government does not interfere with the daily decisions of the fund, while using the form of limited partnership. The total capital of the government is less than $40 \%$. Most of the invested industries or projects belong to high-risk projects just at that moment. The private capital and overseas capital participate in high risk investment projects continuously under the exemplary role of government guidance funds. The government investment basically achieve the exit when enterprises in the development of more mature to inject a strong impetus for the subsequent development of investment fund.

Australia's Government venture capital guidance fund was set up late in 1997 by the prime minister. The purpose of IIF is mainly to improve the speed of Australia's commercial patent industrialization, and to promote the development of Australian venture capital market and cultivate local venture capitalists. The basic idea of the government is to benefit the people and not fight the interests of the people. The total scale of the guiding fund is 221 million US dollars, which stipulates the highest and the lowest proportion of government capital and private capital and pays attention to the investment of early venture capital enterprises in the choice of investment direction. The financing of the guidance fund is completed through two stages. The first stage is 130 million dollars and the second stage is 40 million dollars for the government. The demand for the first investment must be the early investment of the venture capital, and the $60 \%$ of the fund must be fully invested in five years. In 1992, Australia passed the PDF bill, which is a supplement to the IIF plan, mainly to cultivate and develop Australia's long-term capital market. PDF also provides the corresponding tax incentives for 
the invested enterprises and makes corresponding restrictions that only those industries that are mainly supported by the Australian government can enjoy the preferential tax revenue provided by the government.

\subsection{Financing Guarantee Mode}

The way of supporting venture capital in the US and Germany is different from that in Australia and Israel. First, a venture capital guiding fund is established through the government's funding. The guiding fund provides support for the development of enterprises in the form of financing guarantee. The investment direction is mainly high-tech industry. It pays more attention to the support of the early enterprise. It has achieved good comprehensive benefits and nurtured a number of venture capitalists.

The support of SBIC program in the US has two stages: one stage is to provide financing for SMEs directly, and this stage is from 1958-1994 years. The second stage is after 1994. With the continuous development of the financial market, the government's support for small and medium-sized enterprises is mainly to provide financing guarantee. In addition to the SBIC plan mentioned above, the US government has also developed a NWVC program to promote the development of venture capital industry in low income areas. NWVC plans to invest less than 50 thousand dollars, and $80 \%$ of the total amount of money is invested in low income areas.

The German government began implementing the venture capital loan guarantee plan in 1989. The plan provides guaranteed interest free loans as the main way to support venture capital enterprises. The repayment period of loans is ten years with a total capital of one million Mark. It has been proved that the project has been successful and has nurtured the development of the small and medium enterprises in Germany.

\subsection{A Diversified Way to Support Venture Capital Enterprises}

It is represented by the UK. The most important way to support venture capital companies is to participate in venture capital funds, supplemented by government guarantees, tax preferences and other supporting measures.

The venture capital industry in Britain has developed the earliest in Europe. Although its development trend is not as strong as that in the US, there are still many advantages in the UK's venture capital program. The early involvement in venture capital institutions in the UK is a trust agency, and there are various forms of private fund in the UK. From the source of capital, the capital of venture capital in the UK includes pension funds, insurance company funds and overseas capital. As the British government has a special preference for overseas capital, overseas capital is actively involved in the venture capital activities in the UK. In 1995, the UK passed the VTC act, which encouraged private capital and overseas capital to actively participate in the venture capital trust fund.

\section{Experience Analysis on The Operation of Guidance Fund in Different Countries}

The government set up venture capital guidance fund to establish a venture capital mechanism consisting of venture capital fund, venture capital manager and industrial capital. The government should guide private capital and overseas capital to actively participate in the venture capital activities of our country through the amplification function of the fund, so as to promote the industrialization of new invention patents and achieve industrial upgrading. Through the comparative study of the operating mode of the guidance fund in the developed countries, the following experience can be obtained.

\subsection{The Government Has Created A Policy Environment Suitable for The Development of Venture Capital}

(1) Building a good legal environment 
The prerequisite for the development of the venture capital industry is that the government needs to introduce the relevant laws and regulations. The US government promulgated the "small business investment law" in 1958, allowing small and medium-sized investment companies to be established. SMEs can apply for SME's investment company to get relevant preferential loan support, so that venture capital industry has made considerable progress. The Israeli government is directly funded by the government to set up a YOZMA program, the program was initially controlled by the government, but the choice of which company depends on the competition between the companies. At the same time, the Israeli government set up the chief National Office of science to help the venture capital fund in R \& D activities. The Australian guidance fund plan was first proposed by the prime minister in the small business statement and then formed its own IIF plan. In the later stage, the Australian government also put forward the PDF act, which is mainly to promote the industrialization of patent technology, and at the same time, it has made relevant provisions about the nature of the investment enterprise that they cannot invest in retailing and other property activities. The Japanese government followed the United States government in 1963 and launched the "Japanese SME Investment Law". And the government established "corporate investment of SMEs incubation in Tokyo and around Tokyo. After that, the activity of venture capital has been vigorously developed in Japan. In late 80s, the new technology with computer technology as a symbol of the emergence set off a wave of investment. The British government passed the venture investment trust act in 1995 which actively encouraged private capital to participate in the management of venture capital. The French government supports the venture capital management activities through the 79 provisions of the financial law, which stipulates the requirement for the establishment of the subscribed equity of the venture capital enterprises. The French small and medium enterprises Guarantee Corporation is the main means of the French government's support for venture capital, playing an important role in venture capital in France, supporting France's venture capital activities by providing guarantee.

(2) The relevant preferential tax conditions have been set up

The tax law of the United States is clear that limited partnership companies and general partnership companies can enjoy the corresponding tax preferences, but the two types of tax entities are not independent. The current "Regulations" to promote industrial upgrading have different levels of tax incentives to engage in high-tech industry investment projects. In the "economic recovery tax law", which was promulgated in 1981, the tax rate of private capital value added tax was clear, and the rate of tax rate dropped from $28 \%$ to $20 \%$. This tax law has greatly promoted the private capital of the United States to participate in Entrepreneurship in the capital, and the total increase of venture capital. The IIF plan of Australia agreed that the equity investment of start-up enterprises is taxable at $15 \%$ tax rate. Meanwhile, PDF plan shareholders can be partially exempted from income tax when they share dividends. The government of Singapore gives tax incentives to the newly established venture capital fund for seven to ten years, and if the venture capital fund has three consecutive losses, the government will provide the corresponding tax deduction policy compensation, which can get the equivalent of $50 \%$ of the total investment of government subsidies. The British government to stimulate investment by providing personal income tax relief to the unlisted companies, the maximum annual amount of 40 thousand pounds to offset.

(3) Standardizing the order of trade

Under the condition of relevant laws and regulations, the development of venture capital market also depends on the government's regulation of market order and effective supervision of funds. The general government has in guiding fund in the veto power, which guide the fund in the direction of investment from government guidance or in violation of the Charter of the fund, the government needs to be rejected. The US Securities Act Amendment 1975 has clearly stipulated the qualification examination confirmation and the listing conditions of venture capitalists.

\subsection{Guidance Fund Put Forward Specific Requirements for the Operation of Mixed Funds}

The establishment of the guiding fund is to solve the problem of private capital's failure in some investment fields. The guiding fund usually puts forward some specific requirements through equity participation in other investment funds. The above three models are different, but they are all hoping 
to attract private capital from the government to solve the problem of the failure of the investment region. The investment from the government can effectively reduce investment risk. Most countries have a deficit of investment and a corresponding tax compensation mechanism, which effectively stimulate the enthusiasm of private capital investment. The guiding fund is the government's capital and the taxpayer's money. In order to ensure the operation efficiency of the state-owned capital and prevent the loss of state-owned assets, the guiding fund will also make some profit requests. The US SBIC plan requires the establishment of SME investment fund must meet the requirements of the application, and then provide preferential loans to support, and assess its investment value, and then exit. The duration of that period is generally seven to ten years. On the investment project, SBIC $60 \%$ 's funds were invested in small businesses in the seed and initial stages. Investment funds for manufacturing, transportation and services account for $70 \%-80 \%$. This is due to the strict restrictions on the direction of investment by the SBA to control the flow of funds to the risk of the flow of funds.

\subsection{The Guidance Fund Generally Takes the Benefit of the People}

In order to attract the private capital into the guidance fund and increase the "leverage effect" of the guidance fund, the guidance fund will generally take the benefit of the people. The capital gap of the venture capital enterprises is the largest in the seed period and the initial stage. The investment risk is the biggest in this period, which belongs to the period of failure in the private investment field. The guidance fund can stimulate the enthusiasm of private capital through the practice of helping the people, and this measure can effectively attract related capital into the guidance fund. From Israel's experience, the establishment of the two-leading fund YOZMA fund and the INBAL fund, INBAL fund is taking a more prudent investment than the YOZMA fund, namely the government provides financing guarantee for its investors, even after 7-10 years the investors can get up to $80 \%$ of the insurance commitment, which greatly mobilized the enthusiasm venture investment fund, and the investment sub-funds have made good gains. With the strong support of the Israeli government, great success has been achieved in the venture capital at the stage of research. The data show that the corresponding rate of success in other countries of the same period is $10 \%$, while Israel is up to $50 \%$. Under the condition of mature management and proper management, the government investment guidance fund has chosen to quit, and the operation income of the fund has been owned by investors, which has promoted the vigorous development of the risk investment industry in Israel.

\subsection{Guidance Fund Pays Attention to the Innovation of Support Mode at Different Stages of Venture Capital Development}

From the perspective of SBIC plan in the US, the early government investment guidance fund is mainly based on loans that offer preferential interest rates. This is because the development of venture capital market is not mature enough, and enterprises get financing difficulties. They need direct investment from government investment funds. In the mature market of venture capital, the government can provide preferential loans and provide corresponding tax incentives and credit guarantee mechanisms to help conditional Venture capital enterprise get bank loans. Under the condition of mature capital market, the government is more focused on indirect means of regulation. The government needs to clarify the principal agent relationship in the form of relevant legal provisions, which can prevent moral hazard from happening. In different stages of venture investment, because of the different degree of confidence between professional managers and venture capitalists, it is bound to affect the capital efficiency of venture capital. In the United States, in order to solve similar problems, the OTC market and NASDAQ market are mainly established, and the information opaque problem in venture capital is solved through market trading discovery mechanism. The NASDAQ stock market is growing with the development of the venture capital industry in the United States, and the volume of the stock market has exceeded the share of the New York stock market. Other countries have also set up their own SME board market and OTC market. 


\subsection{The Venture Capital Fund Should Pay Attention to the Training of the Market Mechanism of Venture Capital}

From the experience of the guiding funds in the above countries, no matter which tool we use to support venture capital companies, governments all attach great importance to supporting venture capital enterprises without competition. The principle of not intervening competition is also a necessary means to cultivate a good venture capital market. The government cannot abuse the power to interfere in the competition between the venture capital enterprises and other enterprises and disrupt the choice of the market mechanism. Most of the projects supported by the government are pre-competition projects. Most of the projects in competition are indirectly funded by indirect means. The most common ones are credit guarantee and preferential tax policy.

It is a systematic project to cultivate a perfect venture capital market, and venture capital is not only investment but also a kind of financing. To establish a perfect market for venture capital, it needs to improve the market subject and the multi-level talent system. The venture capital not only includes the previous investment, but also establishing a perfect two-level trading market to realize the exit or transfer. In the late 70 s of last century, the demonstration effect of the venture capital fund further strengthened the market position of the venture capital investment. The United States government has timely launched a series of policies to meet the requirements of the financial market at seed, development and mature enterprises. For the development of perfect and mature enterprises will generally be listed in the first level market, and the corresponding barriers to listing are higher. As for the investment risk, the enterprises that are not mature enough will be traded in the two-level market. In addition to the matching market trading system, the US government has made policy provisions for talent introduction. Under the joint action of talent policy and market policy, the US has established a perfect venture capital market system in the world.

\section{Policy Suggestions on China's Venture Capital Guidance Fund}

\subsection{Correctly Select the Operation Management Model of the Venture Capital Guidance Fund}

All countries have formed their own mode of operation. Israel and Australia form their own fund participation mode, the United States and Germany have formed their own financing guarantee mode, and the UK has formed its own diversified support mode. Every country has chosen the investment development mode suited to their national conditions according to local conditions. China has vast territory and uneven economic development. Different regions also form their own development models, such as Beijing mode, Tianjin mode, Shanghai mode and Shenzhen mode. The selection of these guidance funds should be based on the involvement of the local government.

Different modes of operation can be tried in areas with different development levels of the venture capital industry. In the early stages of the development of venture capital, in order to develop its venture capital quickly, it is generally adopted directly to support the development of venture capital. Generally, and it is represented by the mode of participation and the model of compensation fund. On the development of venture capital of more mature regions, through some indirect means of investment, such as tax offset and financing guarantee form. It can constantly attract social capital to participate in venture capital activities with the continuous development and improvement of the market.

\subsection{To Liberalize Regional Investment Restrictions and to Set up Mixed Funds}

It is disadvantage for the comprehensive development of the guidance fund due to the corresponding provisions by government guidance funds for most investment areas. This is because if the guidance fund is restricted to a certain area, the fund will not get a good operation if lack of corresponding high-quality projects or enterprises with investment value. According to the experience of developed countries, the development of venture capital is generally concentrated in some areas. Most of the venture capital companies in the US are in Massachusetts and California. Among them, the most important part of California is the surrounding areas of Silicon Valley. And in Japan, the 
major investment industry is concentrated in the industrial zones of Tokyo, Osaka and Nagoya. From the development of our country, the guidance fund is mainly concentrated in the developed areas such as Beijing, Shanghai, and Shenzhen and so on. The guidance fund should be given the function of guiding regional investment, and the local governments should be encouraged to establish guidance fund through cooperation and promote the coordinated development of the region.

\subsection{To Perfect the Exit Mechanism of Venture Capital Guidance Fund}

According to the investment experience of the foreign guidance fund, it is not possible to withdraw from the venture capital enterprise too early or too late to give full play to the effect of the guidance fund. From the experience of Israel, a guiding fund was established in 1991 and the government chose to quit altogether in 1998. It was a total of 7 years during that period. The experience of the US is that the financing plan of SBIC is generally 7 to 10 years. The supported project can be properly extended, but it should be withdrawn in time after the expiration of the term. At the same time, the multi-level venture capital market system is developed to provide a good exit channel for the venture capital. In addition to developing publicly issued stock market and gem market, we should also improve relevant property rights market and private placement market, so as to provide a convenient and effective access for venture capital exit.

\subsection{Weakening the Profit Requirements of the Guidance Fund and Strengthening the Guiding Role}

Taking SBIC in the US as an example, in order to promote the development of venture capital industry, the US government decreased the capital gains tax from $49.5 \%$ to $28 \%$ in 1978 , which greatly promoted the development of venture capital industry. And the economic recovery tax act of 1981 further adjusted the value of VAT to $20 \%$, which doubled the total amount of venture capital in the year. Because in the initial stage of venture capital, the guiding fund often faces the failure of the project. If the government wants to achieve the goal, it should focus on those high-risk and high-tech projects and invest in the seed period of the enterprises. The government should introduce the corresponding tax policy. At the same time, the method of assessing the performance should take into consideration the social and economic benefits of the guidance fund.

\section{References}

[1]. Amati AR, Pfleiderer P. Robust Financial Contracting and the Role of Venture Capitalists. The Journal of Finance, 1994, 49(2): 371-402.

[2]. Bashir HA, Thomson V. Models for Estimating Design Effort and Time, Design Studies, 2001, 22(2): 141-155.

[3]. Black BS, Gilson RJ, Venture capital and the structure of capital markets: banks versus stock markets. Journal of Financial Economics, 1998, 47(3): 243-277.

[4]. Burton GD, Ahlstrom D. An institutional view of China's venture capital industry: Explaining the differences between China and the West. Journal of Business Venturing, 2003, 18(2): 233259.

[5]. Burton GD, Fried VH, Minimart S. Institutional influences on the worldwide expansion of venture capital. Entrepreneurship Theory and Practice, 2005, 29 (6): 737 -760.

[6]. Buzzacchi L, Stellate G, Ghetto E. The investment strategies of publicly sponsored venture capital funds. Journal of Banking \& Finance, 2013, 37(3): 707-716.

[7]. Chaka J, Smut SM, Agrawal A. Life sciences venture capital in emerging markets. Nature Biotechnology, 2013, 31: 195-201. 
[8]. Cumming D, Schmidt D, Waltz U. Legality and venture capital governance around the world. Journal of Business Venturing, 2010, 25(1): 54-72.

[9]. Ewes M, Jones CM, Rhodes-Kopf M. The Price of Diversifiable Risk in Venture Capital and Private Equity. The Review of Financial Studies, 2013, 26(8): 1854-1889.

[10]. Gilson RJ, Schemer DM. Understanding Venture Capital Structure: A Tax Explanation for Convertible Preferred Stock. Harvard Law Review, 2002, 116: 874-916.

[11]. Hellmann T, Lindsey L, Pure M. Building Relationships Early: Banks in Venture Capital. Review of Financial Studies, 2004, 21(2): 513-541.

[12]. Hochberg YV, Ljungqvist A. Informational Holdup and Performance Persistence in Venture Capital. The Review of Financial Studies, 2013, 27(1): 102-152.

[13]. Jing LA, Wells PC. The determinants of venture capital funding: evidence across countries. Journal of Corporate Finance, 2000, 6(3): 241-289.

[14]. Keuschnigg C, Nielsen SB. Public policy for venture capital. International Tax and Public Finance, 2001, 8(4): 557-572.

[15]. Kemmerer W. Comparing catalysts of change: evolution and institutional differences in the venture capital industries in the U.S., Japan and Germany. Research on Technological Innovation, Management and Policy, 2001, 7: 227-261.

[16]. Cullman S. Future governance of innovation policy in Europe - three scenarios. Research Policy, 2001, 30(6): 953-976.

[17]. Ouzel U, Robinson DT, Stuart TE. Stuart Strategic alliances, venture capital, and exit decisions in early stage high-tech firms. Journal of Financial Economics, 2013, 107(3): 655-670.

[18]. Reinhardt CS. Lessons and Memories from the North-western Training Program in Methodology and Evaluation Research. The American Journal of Evaluation, 2003, 24(2): 273276.

[19]. Salmenkaita JP, Silo A. Rationales for government intervention in the commercialization of new technologies. Technology Analysis \& Strategic Management, 2002, 14(2): 183-200. 